\title{
University Libraries in the Americas: The Inter-American Seminar
}

BY MARIETTA DANIELS

$S^{\circ}$

OME TWENTY LIBRARIANS representing equally university libraries in North and Latin America, met January 25-27, 1961, at Allerton House, Monticello, Illinois, for an Inter-American Seminar on University Libraries. This meeting was the first of a series of specialized conferences to be called as a part of the program of the Council on Higher Education in the American Republics (CHEAR), administered by the Institute of International Education, supported since 1958 by the Carnegie Corporation with the assistance of the Ford Foundation since 1960.

CHEAR was created for the purpose of developing close personal ties among educators in the Americas and of providing a forum for the informal discussion of mutual problems in higher education. Its objectives are accomplished by three principal activities: 1) a series of small annual conferences of selected Latin and North American educators to discuss problems of higher education in the hemisphere; 2) visits by participating educators to member universities; and 3) the development and carrying out of studies, projects, and seminars designed to meet educational needs specified at the annual meetings.

A study on inter-American scholarly communications in the humanities and the social sciences, carried out as one of the first major undertakings of CHEAR, revealed that such communication was poor at best. ${ }^{1}$ Recognition by CHEAR

1 Frederick Burkhardt. "Inter-American Scholarly,
Communication in the Humanities and Social Sciences," Communication in the Humanities and Social Sciences,"
Miss Daniels is Associate Librarian, Pan American Union, Washington, D. C.

of the importance of the university library in the communication of information led to the informal seminar for university librarians, organized by the Institute of International Education.

Latin American university librarians, in addition to attending the seminar, visited several U. S. university libraries, and U. S. participants unacquainted with Latin American libraries toured universities in Mexico and Central America to familiarize themselves with current practices in these areas.

Under the co-chairmanship of Manuel Alcalá, director of the National Library of Mexico, which functions as a dependency of the Universidad Nacional Autonoma de Mexico, and Jack Dalton, dean of the School of Library Service of Columbia University, the participants explored the principal problems which affect library services in the Americas.

To provide a common basis for understanding during discussions, considerable time was spent at the outset of the seminar in delineating the principal concepts, characteristics, and functions of modern universities and university libraries in both Latin and North America. Subsequent sessions were mainly concerned with three areas of discussion: 1) characteristics of universities as they affect university libraries; 2) the personnel of university libraries and their 
training; and 3) deterrents to progress in the development of university libraries, especially in Latin America.

\section{Characteristics of Universities as They Affect University Libraries:}

a. Autonomy of the University. The autonomy of faculties within a university, in both the United States and Latin America, is reflected in the lack of central libraries in many institutions. In the United States, and in some instances in Latin America, the appointment of a "director of libraries" has been made to coordinate, if not to centralize, university library administration as a means of resolving the difficulties.

b. Teaching Methods. Professors, especially in Latin America, have until recently tended to accumulate their own private library collections and to teach from personal notes with rare assignments of "outside reading." The situation has resulted in relatively little attention being given to institutional libraries.

c. The Tendency towards Generalization. A higher degree of specialization throughout the university curriculum is seen in Latin America than in the United States, probably because of the broader general instruction given in the Latin American secondary schools. Professions themselves have been closed ones, and there has been little or no cross-fertilization by using the same faculty for similar courses taught in several schools, or offering certain courses of mutual interest to students in various schools. Narrow specialization, however, is giving way in Latin America, as it has in the past in the United States, to greater generalization of studies in the early years of university education, wherein certain courses are required for all students whatever their eventual specialty will be. The growing emphasis upon two to four years' "liberal education" within the university increases the need for greater library facilities.

d. The Role of Research in the University. The emphasis on research in university activities is seen to be on the increase, though such activities vary considerably between small colleges and large universities in the United States and in universities in Latin America. It is expected that in Latin America, as part-time gives way to full-time staffing, faculty research will be even further emphasized. This will entail the development of reference and readers' services for faculty andespecially in Latin America-for the university student who has not had the benefit of school and public libraries where he could learn how to locate information and utilize the tools of the librarian and investigator.

e. The Physical Location of Faculties, and New University Cities. When individual faculties are dispersed throughout the city, small general rather than specialized libraries are developed in each to satisfy the reference needs for teachers and students, whether they be of a general or specialized nature. Even with the construction of large university cities, the proliferation of these general collections with their duplication of labor and material continues. A similar condition exists in the United States today, where the size and complexity of universities tend to increase the decentralization of university library 
collections and the creation of divisional libraries outside the central library building.

\section{The Personnel of University Librar- ies and Their Training}

In the United States, formal professional training for librarians is given in the fifth university year, normally after the student has earned a degree in liberal arts and sciences. In Latin America, permanent library schools are usually on a lower level because although the need for technical preparation of library personnel is recognized, efforts in this direction have been discouraged by the fact that the salary level and professional status of librarians have been traditionally low. It is noted, however, that although training has not yet reached university level, it has progressed over the years from one-year courses to four-year courses combining general studies with technical subjects. A noteworthy attempt to improve the training of librarians is seen in the Inter-American Library School in Medellín, Colombia. Created by a grant from the Rockefeller Foundation for the providing of a minimum of academic and technical education for library personnel from those countries unable to support anything more than short-term orientation courses, it serves as an experimental center for library training and offers facilities for advanced specialized studies as well.

3) Deterrents to Progress in the Development of University Libraries, Especially in Latin America

In addition to the prevalence of inadequate personnel and the general absence of centralized or coordinated library services, the dearth of information about current developments in library science outside Latin America and the scarcity of technical tools are recognized as major deterrents to progress. The lack and/or non-availability of bibliographic information on current books and peri- odicals creates a more serious problem for Latin American than for U. S. university librarians. For example, the working papers, studies and summaries of discussions, of conferences, and seminars on library science (in particular, the Seminar on the Acquisition of Latin American Library Materials)_in many cases the best or only documents available on the various aspects of bibliographic and acquisition problems and information sources-sponsored by inter-American educational institutions, have been given inadequate distribution. Moreover, equipment essential to the librarian, adapted to the needs of Latin America and its languages, is almost wholly lacking. Until this is made available and uniformity of practice is achieved by the use of this equipment, there will continue to be waste of time and effort in individual libraries in processing library materials, and progress in cooperative cataloging will remain virtually impossible.

From these discussions, the following findings emerged:

\section{The Need for Centralization and/or Coordination of Library Services}

There is an increasing need for establishing a central university library with direct or indirect control over all libraries in the university, or at least coordinating university library services by the appointment of a "director of libraries" with recognized authority. Either plan, or a combination of the two, would: (a) assure more economical use of financial resources by permitting centralizing acquisition procedures which would preclude the needless duplication of books and expensive periodicals, and reduce personnel labor and expenses involved in duplicating activities; (b) afford better use of personnel by allowing those technically specialized to be employed in the technical organization of all university libraries and those subjectspecialized personnel to be employed ef- 
fectively in faculty and institute libraries by assisting in reference and research; (c) afford immediate access to frequently needed material and economical storage for little-used material; and (d) increase the possibility of cooperative acquisition and cataloging among the libraries of various universities, whereby uniformity of procedure would be achieved, the duplication of little-needed materials would be avoided, and the wider distribution of bibliographic information would be made feasible.

\section{The Need for Increasing Inter-Com- munication of Librarians, Faculty, and University Administrators}

If rectors and faculty remain unaware of the proper function of the library in university teaching and research programs, the librarians cannot expect to have either the financial or moral support required to service the university or to respond to its present or future informational and research needs. Therefore, to encourage the faculty's understanding of library needs and potential services, and the library staff's understanding of faculty teaching and research needs, increased effort should be made to achieve a closer working and professional relationship between the two groups. The participation of the chief librarian or director of libraries in the administrative council of the university is to be equally encouraged as a means of assuring a more effective role of the library in the university program.

\section{Training of the Professional Librar- ian}

Although some progress has been made in the past few years towards increasing proficiency within the field of library science, concentrated efforts in this direction are needed to perfect and intensify the recruitment and training of librarians, to raise their economic and professional level, and to enhance their opportunity to attain a desired "faculty status." Most urgently required, in this respect, are: (a) the recruitment of more and better library school students and faculty; (b) the placing of a library school within the university (with a minimum requirement of four-years' study, including academic and professional courses) where matriculation requisites and standards of achievement would be determined as they are for other professional schools in the university, and after which training, professional and official recognition would be assured; (c) the providing of increased professional and special pedagogical training for teachers of library science now in service; and (d) the providing of orientation and in-service courses for personnel employed in university libraries to give them minimum technical training, especially for routine library work.

\section{Extending Inter-American Exchanges}

The formation of a corps of U. S. librarians especially prepared to give technical assistance and advice to Latin American librarians, and the increase of fellowships or scholarships for Latin Americans for advanced study in library science in the United States are recommended, as well as is an increased participation of librarians in conferences, seminars, and meetings relative to their profession.

\section{The Need for a Survey to Determine Priority Action}

It is recognized that before the improvements mentioned above can be effected, a study in depth of the current situation of university libraries, especially in Latin America, is essential. To this end, consideration might be given to the financial support of an expert in university libraries to conduct an investigation of the present condition of university libraries and to determine the priority of those special studies and surveys which should be carried out for the 
benefit of governments, foundations, international agencies, and educational institutions planning for the improvement of universities and university libraries in this hemisphere.

The Latin American participants in the CHEAR Inter-American Seminar on University Libraries, in addition to Cochairman Alcalá, were Luisa Arce, Universidad de Chile; Edson Nery da Fonseca, Biblioteca de Camara dos Deputados, Brasilia; Mrs. Carmen D. de Herrera, Universidad de Panamá; José Lazaro, Universidad de Puerto Rico; Maria Luisa Monteiro de Cunha, Universidad de São Paulo; Carlos V. Penna, UNESCO, Havana; Jaime Quijano-Caballero, Universidad Nacional de Colombia; Esther
Dosil de Ramírez, Universidad de la Repüblica, Uruguay; Josefa E. Sabor, Universidad de Buenos Aires; Maria Teresa Sanz, Universidad Católica de Chile; and Carmen Rovira, Pan American Union, who acted as interpreter.

Participants who attended the CHEAR seminar from the United States, in addition to co-chairman Dalton, were: Marietta Daniels, Pan American Union; William V. Jackson, University of Illinois; Stephen McCarthy, Cornell University; Philip McNiff, Harvard University; Raynard Swank, American Library Association; Robert Talmadge, Tulane University; Robert Vosper, University of Kansas; and Stanley L. West, University of Florida.

\section{The Dag Hammarskjold Library}

The United Nations dedicated its new library, built by a grant from the Ford Foundation, at a special meeting in the General Assembly Hall on Thursday, November 16, 1961 in memory of the late secretary general. Out into the marble wall in the hall opposite the entrance door are the words, "The Dag Hammarskjold Library; Gift of the Ford Foundation, 1961." The inscription is the result of two unanimous decisions by the General Assembly. On October 16, 1961, the Assembly, acting on the suggestion of the Ford Foundation, and "desiring to establish an appropriate memorial" commemorating Mr. Hammarskjold's services to the United Nations, decided to name the library in his honor. On November 3, 1959, the Assembly had accepted "with highest appreciation" the Foundation's gift of $\$ 6,200,000$ for the construction and equipment of the library.

The library is located on the south side of the main courtyard at United Nations headquarters. It will house some
400,000 books, nearly double the present collection.

Mr. Hammarskjold had arranged a two-day library symposium in connection with the dedication, which was attended by more than thirty leading librarians of as many countries, and by some eighty to ninety United States librarians. Included were such well-known figures as Dr. Uno Willers, national librarian of Sweden; Sir Frank Francis, director and principal librarian of the British Museum in London; Dr. Quincy L. Mumford, librarian of Congress in Washington, D. C.; Edward G. Freehafer, director of the New York Public Library; Dr. Bogdan Horodyski, director of the Polish National Library in Warsaw; Douglas W. Bryant, associate director, Harvard University Libraries; Verner W. Clapp, president and director of the Council on Library Resources, Inc.; Dr. Frank Rogers director of the National Library of Medicine, Washington, D. G.; and Dr. Frederick H. Wagman, director, University of Michigan Libraries. 